\title{
RESOURCE SECTOR PERSPECTIVES ON CANADIAN COMPETITION POLICY
}

WILLIAM R. PRUETER*

\begin{abstract}
This paper provides a general background review and current update as to the legislative development of the existing Combines Investigation Act, concentrating on the application or non-application of the existing legislation to selected activities common to the exploration and production sector. In addition, it reviews selected resource sector concerns respecting current proposals for legislative change.
\end{abstract}

\section{INTRODUCTION}

The purpose of this paper is to provide a general background review, update, and perspective with respect to the development and current status of selected aspects of Canadian competition policy, as reflected in the existing Combines Investigation Act ${ }^{1}$ and proposed legislation. The viewpoint adopted is that of the petroleum resource sector in general, with special emphasis on exploration and production related activity in particular.

This paper does not deal in any detail with the application of the Combines Investigation Act, or the potential application of pending legislative changes to such matters as retail and industrial marketing practices, or a multitude of areas which might be usefully reviewed within the context of this topic, and which might be relevant to aspects of the functioning of many Canadian resource corporations. Additionally, it is not intended to review, in detail, the case law which has developed under the existing Combines Investigation Act, and which has already been subject to extensive analysis.2

\section{HISTORICAL PERSPECTIVE}

A full understanding of existing and proposed legislative changes necessitates an historical perspective, and the 1952 Report to the Committee to Study Combines Legislation (selected portions of which are reproduced in Appendix A) is a useful point of commencement in reviewing the period 1888 to $1952 . \mathrm{s}$

The origins of many of the current legislative trends in the reform of Canadian competition policy may be found in a Special Reference from the Federal Government to the Economic Council of Canada on July 22, 1966, This was a direct request to the Council to study and advise, in the light of the Government's longterm economic objectives, "combines, merger, monopolies, and restraint of trade", 4 and culminated, in July, 1969, in the publication of an Interim Report on Competition Policy (the "Interim Report").

- Member of the Ontario Bar.

1. R.S.C. 1970, c. C-23, as amended by 1st Supp., 10; 2nd Supp., 10, and S.C. 1974-74-76, 76.

2. See Skeoch, Restrictive Trade Practices in Canada (1966).

3. See, Report of the Committee to Study Combines Legislation 9-15 (1952). Reprinted by permission of the publishers.

4. Economic Council of Canada, Interim Report on Competition Policy 1 (1969). 
The Interim Report concluded that such dynamic change had taken place in the Canadian economy since the date of the earlier inquiry by the MacQuarrie Committee in 1951-523 that a background study, designed to form a basis for new legislative programs, was warranted.

In June, 1971, following review of the Interim Report, the Minister of Consumer and Corporate Affairs, Mr. Ron Basford, presented Bill C-256 for first reading in the House of Commons.

It was indicated when Bill C-256 was introduced that it was not the intention of the Minister to carry Bill C-256 through the legislative session. Rather, the Bill was to be utilized as a basis for eliciting widespread discussion, with a view to "perfecting" legislation. 6

The Canadian business community in general, and the resource sector in particular, were seriously concerned about many of the provisions of Bill 256. It became apparent to the Government that there were serious complications inherent in drafting omnibus legislation of general application to a wide variety of sophisticated forms of business activity.

In December, 1971, the Canadian Petroleum Association filed a lengthy submission with the Minister of Consumer and Corporate Affairs.7 In the brief, the Association registered extensive concerns relating to the potential impact which Bill C-256 might have on the operations of the some two hundred member companies who were engaged in oil and gas exploration, development, production, gas processing and pipeline operations in Canada.

In basic terms, that submission, and many of those which have followed, recommended that the philosophy of the Act be reconsidered to assure the development of a realistic competition policy that will, to the greatest extent possible, be geared to the total public interest and the economy as a whole, while continuing to ensure that the legislation contains only such restraints against freedom of business action considered absolutely necessary to achieve such purpose.

Following the election of Pierre E. Trudeau's minority Liberal Government in October, 1972, an incremental approach to the introduction of Canadian competition policy was adopted. A new Minister of Consumer and Corporate Affairs announced on July 18, 1973 that reform of Canadian competition policy would be reintroduced in two distinct stages.

\section{STAGE I AMENDMENTS}

The first stage amendments to the existing Combines Investigation Act received first reading as Bill C-227 and, following review by Senate and House Committees, received third reading in the House of Commons in October, 1975. With one exception (the section prohibiting agreements and conspiracies limiting competition in the service industries, which came into force on July 1,1976 ), Stage I became effective on January 1, 1976.

\section{Id. at 2.}

6. Report of the Director of Investigation and Research, Combines Investigation Act, for the Year Ended March S1, 1975, 10.

7. Submission of the Canadian Petroleum Association to the Minister of Consumer and Corporate Affairs Respecting Bill C-256, (1971). 
In general terms, from the point of view of the exploration and production sector, the Stage I amendments, while significant to fully integrated resource operations, were not as controversial as those proposed for the so called Stage II amendments.

The Stage I amendments, in summary form, introduced the following changes:

\section{A. Regulation of the Service Industries}

Prior to the implementation of Stage I, the Combines Investigation Act was directed at restraint of trade, and trade practices in relation to dealings in articles and commodities of trade: it had no application to services or service industries, although certain specific industries, such as storage, transportation and insurance were included. In accordance with the general direction recommended by the Economic Council of Canada,8 and the trend towards expanding the application of the Act, the Act was extended to apply to all services and service industries, which include, for example, the activities of all professions, lawyers, physicians, engineers and architects, financial institutions, consulting firms, real estate agents, etc.

This change was accomplished by substituting the word "product" for the word "article" to include both an article and a service. The word "service" was defined broadly in Section 1 (5) of the 1976 amendments as follows:

'service' means a service of any description whether industrial, trade, professional or otherwise.

According to the Annual Report of the Director of Investigation and Research for $1976 ; 9$

As a result of the inclusion of services under the scope of the Act, all economic activities will be subject to the Act, except those that are specifically exempted by the Act itself or.as a result of other legislation, thereby making the coverage of the Act more rational in modern economic terms and eliminating the enforcement difficulty of distinguishing aspects of a business which relates to services and those which relate to commodities.

\section{B. Reviewable Practices}

The Stage I amendments did not make the major structural changes which had originally been suggested in Bill C-256. Instead, they provided that the Restrictive Trade Practices Commission would retain its existing functions and, in addition, would be empowered to review and make orders in respect of five trade practices described as "refusal to deal",10 "consignment selling"," "exclusive dealing", "tied selling", and "market restriction".12

The Commission was also authorized to review situations where foreign judgments, laws and directives are applied in Canada, as well as cases of refusal to supply by foreign suppliers to a person in Canada.

8. Economic Council of Canada, supra, n. 4 at 157 et seq.

9. Annual Report, Director of Investigation and Research, Combines Investigation Act, for the Year Ended March S1, 1976, 10.

10. Combines Investigation Act, supre n. 1 as amended by S.C. 1974-75-76, 76, s. 31.2 (hereinafter referred to as "the amended Act").

11. Id. s. 31.3

12. Id. s. 31.4 
The theory behind the creation of categories of "reviewable practices", as opposed to offences which are absolutely prohibited, was that certain forms of agreement between competitors may have anticompetitive effect unless the contrary is shown. Therefore, the Commission should have the full power and authority to convene a public hearing upon application of the Director of Investigation and Research, and to make the appropriate order.

Orders of the Commission are subject to judicial review in the limited circumstances set out in sections 18 and 28 of the Federal Court Act, ${ }^{13}$ which will be considered below.

1) Refusal to Deal

The alleged inability of certain Canadian businesses to obtain supplies required in the ordinary course of business on normal trade terms was considered in the Stage I amendments, and the Director of Investigation and Research may now refer such a matter to the Restrictive Trade Practices Commission.

The section provides for the making of an order by the Commission in "refusal to deal" situations where it finds that: 14

(a) a person is substantially affected in his business or is precluded from carrying on business due to his inability to obtain adequate supplies of a product anywhere in a market on usual trade terms.

The Commission must also find that the person referred to is unable to obtain adequate supplies because of insufficient competition among suppliers, that the person is willing and able to meet the usual trade terms of the supplier or suppliers, and that the product is in ample supply. The Commission may order:15

that one or more suppliers of the product in the market, who have been afforded a reasonable opportunity to be heard, accept the person as a customer within a specified time on usual trade terms...

The expression "trade terms" is defined in the Act to mean "terms in respect of payment, units of purchase and reasonable technical and servicing requirements".16 The Commission may also recommend to the Minister of Finance that custom duties may be reduced to the extent necessary to place the person who is refused supplies on an equal footing with other persons who receive adequate supplies of the article in Canada.

The Act provides that, for the purposes of the refusal to deal provision, an article is not to be considered as a separate product only because it is differentiated from other articles by a trade or other proprietary name unless such article so dominates the market as to "substantially" affect the ability of a potential buyer to deal in that class of articles. The purpose of the subsection is to make it clear that suppliers of "private brands" will not normally be required to make such brands generally available to dealers.

13. S.C. 1970-71-72, 10 (2nd Supp.) as amended.

14. The amended Act, supra n. 10, s. 31.2(1(a).

15. Id. s. $31.2(1)(f)$.

16. Id. s. 31.2(c).

17. Id. s. 31.3 


\title{
2) Consignment Selling
}

The "consignment sale", where title to goods does not pass from supplier to retailer, but rather to the ultimate purchaser directly through the agency of the retailer, was considered in Stage I. A section of the Act now provides that:

\begin{abstract}
Where ... the Commission finds that the practice of consignment selling has been introduced by a supplier of a product who ordinarily sells the product for resale, for the purpose of controlling the price at which a dealer in the product supplies the product, or diseriminating between consignees or between dealers to whom he sells the product for resale and consignees, the Commission may order the supplier to cease to carry on the practice of consignment selling of the product.
\end{abstract}

To the extent, therefore, that "consignment" is introduced by and at the insistence of the supplier, to intentionally circumvent prohibitions against resale price maintenance or price discrimination prohibitions in the Act, the practice is reviewable by the Commission, and may result in an order requiring a supplier to cease the practice.

The critical portion of the section requires the Commission to prove that consignment selling has been introduced as a condition of doing business by the supplier for the express purpose of controlling price. In the resource sector, that has been neither the intent nor the rationale.18

\section{3) Exclusive Dealing,}

\section{Tied Selling}

The "exclusive dealing" section of the Combines Investigation Act defines that term to mean:19

(a) any practice whereby a supplier of a product, as a condition of supplying the product to a customer, requires that customer to

(i) deal only or primarily in products supplied by or designated by the supplier or his nominee, or

(ii) refrain from dealing in a specified class or kind of product except as supplied by the supplier or his nominee, and

(b) any practice whereby a supplier of a product induces a customer to meet a condition set out in subparagraphs (a) (i) or (ii) by offering to supply the product to him on more favourable terms or conditions if the customer agrees to meet the condition set out in either of those paragraphs.

\section{"Tied selling" is defined to mean:20}

(a) any practice whereby a supplier of a product, as a condition of supplying the product (the "tying" product) to a customer, requires that customer to

(i) acquire some other product from the supplier or his nominee, or

(ii) refrain from using or distributing, in conjunction with the tying product, another product that is not of a brand or manufacture designated by the supplier or his nominee, and

(b) any practice whereby a supplier of a product induces a customer to meet a condition set out in subparagraph (a) (i) or (ii) by offering to supply the tying product to him on more favourable terms or conditions if the customer agrees to meet the condition set out in either of those subparagraphs.

18. See Restrictive Trade Practices Commission, Report on an Inquiry into the Distribution and Sale of Automitve Oils, Greases, Anti-freeze, Tires, Batteries, Accessories and Related Practices (1962) and Report of the Gesoline Marketing Inquiry Committee (1969, Alta.).

19. The amended Act, supra n. 10, s. 81.4(1).

20. Id. 
Under Section 31.4(2), if the Commission finds that because exclusive dealing or tied selling is engaged in by a major supplier of a product in a market, or because it is widespread in a market, it is likely to

(a) impede entry into or expansion of a firm in the market.

(b) impede introduction of a product into or expansion of sales of a product in the market, or

(c) have any other exclusionary effect in the market, ...

with the result that competition is or is likely to be lessened substantially, the Commission may make an order directed to designated suppliers of the article or service prohibiting them from continuing to engage in the practice. The order may contain any other requirements which, in the opinion of the Commission, are necessary to overcome the effects in the market or restore or stimulate competition.

It is noted that in such cases the Commission is empowered to issue remedial orders as well as orders to cease the practice.

Insofar as the "tied selling provisions" are concerned, the Act provides for three significant exceptions. An order of the Commission is not to issue ${ }^{21}$ when the tied selling arrangements are reasonable having regard to the technological relationship between or among the products to which it applies, or when it is engaged in by a person in the business of lending money, and is for the purpose of better securing loans made by him and is reasonably necessary for such purpose, or when it is engaged in between or among companies, partnerships and sole proprietorships that are affiliated as defined in the Combines Investigation Act.

\section{4) Market Restriction}

The Commission may make orders in cases of "market restriction", defined as: 22

any practice whereby a supplier of a product, as a condition of supplying the product to a customer, requires that customer to supply any product only in a defined market, or exacts a penalty of any kind from the customer if he supplies any product outside a defined market.

The Commission may make remedial orders prohibiting suppliers from continuing to engage in market restriction and containing any other requirements necessary to stimulate competition, where the Commission finds that because market restriction has been engaged in by a "major supplier of a product" or because it is "widespread in relation to a product", it is likely to substantially lessen competition in relation to the product.

The subsection limits the power of the Commission to make orders with respect to exclusive dealing, tied selling and market restriction by providing that the Commission shall not make an order where: ${ }^{23}$

(i) exclusive dealing or market restriction is engaged in only for a reasonable time to facilitate entry of a new supplier or product into the market, or

(ii) tied selling that is engaged in is reasonable having regard to the technological relationships between or among the products to which it applies, or

(iii) tied selling is engaged in by lenders of money to secure loans, or

(iv) when tied sales are between or among companies, partnerships and sole proprietorships that are "affiliated" as defined in the Combines Investigation Act.

21. Id. ss. $31.4(4)(b) \&$ (c).

22. Id. s. 31.4(1).

23. Id. ss. 31.4(4). 


\section{Civil Cause of Action}

The Combines Investigation Act has traditionally recognized and provided a mechanism for public enforcement. Any six persons resident in Canada, who are not less than eighteen years of age, and who are of the view that a person (or corporation) has contravened or failed to comply with an order under certain sections, or who are of the opinion that an offence has been committed under Part $V$ of the Combines Investigation Act ${ }^{24}$ may apply to the Director to request an inquiry.

Stage I added a new dimension to the recognition of public enforcement. A new section ${ }^{25}$ provides that any person who has suffered loss or damage may bring a civil action for damages resulting from conduct contrary to the Combines Investigation Act up to the full amount incurred, plus costs of investigation and proceedings.

The American legislative precedents contained in Section 7 of the Sherman Act ${ }^{26}$ and Section 4 of the Clayton Act,27 permitting recovery of treble damages in the case of private party claims, have not been carried forward into Canadian law. The right of recovery under Canadian law is an amount equal to the loss or damage proved to have been suffered together with any additional amount which the Court may allow not exceeding the full costs of any investigation in connection with the matter and of proceedings under the section. ${ }^{28}$ Proposals contained in the Stage II amendments respecting class actions are dealt with below.

\section{Offences in Relation to Competition}

\section{1) Conspiracy}

A cornerstone provision of the original Combines Investigation Act was significantly amended in Stage I. The legislation continues to deal with the criminal offence of conspiracy, and, upon violation, carries forward a combination of potentially severe penalties.

The section provides as follows: ${ }^{29}$

Everyone who conspires, combines, agrees or arranges with another person,

(a) to limit unduly the facilities for transporting, producing, manufacturing, supplying, storing or dealing in any product.

(b) to prevent, limit or lessen unduly, the manufacture or production of a product, or to enhance unreasonably the price thereof.

(c) to prevent or lessen unduly, competition in the production, manufacture, purchase, barter, sale, storage, rental, transportation or supply of a product or any price of insurance upon persons or property or

(d) to otherwise restrain or injure competition unduly,

is guilty of an indictsble offence and is liable to imprisonment for five years, or a fine of one million dollars or both.

24. Combines Investigation Act, supra n. 1, 8. 7. This overrules the position stated in Transport Oil v. Imperial Oil Ltd. [1985] 2 D.L.R. 500. and Direct Lumber Co. Ltd. v. Western Plywood Co. Ltd. (1962) 32 D.L.R.1(2d) 227.

25. The amended Act, supra n. 10, 8. 81.1(1). The section does not apply to violation of s. 46.1.

26. Sherman Act, 15 U.S.C.A.

27. Clayton Act, 15 U.S.C.A.

28. Supra, n. 25.

29. Id. s. 32 . 
The concept of "undue" or "unduly" has helped legitimize the legal function for decades. The frustrations of the Crown have been increased by judicial pronouncements which have so restricted the application of the "unduly" principle that, in order to support a conviction, it became necessary to show that the parties had obtained a virtual monopoly over the business carried on in the relevant market.

A line of judicial decisions indicate that, while the meaning of the word "unduly" is a matter of law, whether or not the prevention or lessening of competition by the accused has been undue is a question of fact which can only be resolved in the light of the proven facts of each individual case.

In the 1905 of R.v. Elliott, ," "unduly" was viewed as meaning "in an undue manner or degree, wrongly, improperly, excessively or inordinately". Later, in Weidman v. Shragge, ${ }^{31}$ it was recognized that "it is for the courts to say whether in the circumstances of each particular case the mischief aimed at exists". The fact that actions taken by an accused were prompted by good motives, or whether such action is innocent or even commendable does not, in the view of Mr. Justice Taschereau in the Howard Smith Paper Mills Ltd. decision, alter the true character of the combine forbidden by the law. ${ }^{32}$

In direct response to these difficulties, Stage I introduced a sectionss which provides as follows:

For greater certainty, in establishing that a conspiracy, combination, agreement or arrangement is in violation of subsection (1). it shall not be necessary to prove that the conspiracy, combination, agreement or arrangement, if carried into effect, would or would be likely to eliminate, completely or virtually, competition in the market to which it relates or that it was the object of any or all of the parties thereto to eliminate, completely or virtually, competition in that market.

It is clear that as of January 1,1976 , neither intention nor virtual elimination of competition are required to constitute a violation of the section.

\section{2) Bid Rigging}

The Stage I amendments, directed at alleviating so called "collusive bidding practices," added a new section to the Combines Investigation Act constituting "bidding rigging" as a specific "per se" indictable offence. 34 The effect is that the Crown is relieved of any onus of proving that competition is lessened "unduly" by such action.

Section 32.2 defines "bid rigging" as an arrangement or agreement between persons whereby one or more agree or undertake not to submit a bid in response to a call for tenders or request for bids, or the submission of bids is arrived at by arrangement among tenderers, in each case, where the arrangement is not known to the person calling for tenders at or before the time the bids are made.

30. (1905) 9 O.L.R. 656. See also R. v. Howard Smith Paper Mills Ltd., v. Quben, (1957) 8 D.L.R. (2d) 449; R. v. Aetna Insurance Co. (1975) 12 N.S.R. (2d) 362.

31. Weidman v. Shragge (1912) 46 S.C.R. 1.

32. R. v. Howard Smith Paper Mills Ltd. supra n. 30 at 452.

33. The amended Act. supra n. 10, s. 32(1.).

34. Id. s. 32.2 The Act contains specific exceptions in regard to agreements respecting bidding by "affiliated companies". 
The intention was to prevent collusive bidding practices and to relieve the Crown of the onus of proving that competition was unduly lessened by making the matter a "per se criminal offence".

The section specifically recognized joint venture bids by stipulating, in effect, 35 that no violation will take place if any agreement or arrangement is made known to the person calling or requesting the bids or tenders prior to the time the bid or tender is made. The penalty for violation of this section on conviction may be a fine or imprisonment for a period of up to five years, or both.

In the oil and gas sector, it is clearly the custom for operators to agree on the submission of joint bids at public crown sales, particularly in areas of mutual interest, or where two or more companies are jointly conducting exploration activity.

The fact that a number of companies agree to bid jointly does not preclude other interested competitors from submitting their own tenders. The Combines Investigation Act now assumes that proper disclosure to the Crown will take place at or before the time the bid is submitted, or when a bid is being submitted which is subject to a subsequent back-in by another party, or when, and if, a third party (i.e., a trust company) is bidding.

\section{E. Resale Price Maintenance}

The Stage I amendments made significant changes to section 38 of the Combines Investigation Act, which now prohibits any person who is engaged in the business of producing or supplying a product, or who has the exclusive rights and privileges conferred by a patent, trademark, copyright or industrial design, from attempting by any means whatever to influence upward, or to discourage the reduction of the price at which any other person sells the product within Canada. The section also prohibits any such person from refusing to supply a product or otherwise discriminating against any other person because of the low pricing policy of that other person.

Subsection 38(3) deals with the situation where a supplier suggests a resale price, and provides:

(3) For the purposes of this section, a suggestion by a producer or supplier of a product of a resale price or minimum resale price in respect thereof, however arrived at, is, in the absence of proof that the person making the suggestion, in so doing, also made it clear to the person to who the suggestion was made that he was under no obligation to accept the suggestion, and would in no way suffer in his business relations with the person making the suggestion or with any other person if he failed to accept the suggestion, proof of an attempt to influence the person to whom the suggestion is made in accordance with the suggestion.

The effect of Subsection 38(3) is to place a direct onus on the supplier who suggests a resale price to "make it clear" that the suggestion is only a suggestion, and that business relations with the person to whom the suggestion is made will not be prejudiced if the suggestion is not followed. If it is not made clear, then the mere suggestion of a resale price constitutes affirmative proof that the person making the suggestion is guilty of the offence of resale price maintenance. The common practice, therefore, of stating a suggested resale price with nothing more is no longer in compliance with the Act. 
Subsection $38(4)$, which deals with the advertisements that mention a resale price, should also be noted. The subsection provides as follows:

(4) For the purposes of this section, the publication by a supplier of a product, other than a retailer, of an advertisement that mentions a resale price for the product is an attempt to influence upward the selling price of any person into whose hands the product comes for resale unless the price is so expressed as to make it clear to any person to whose attention the advertisement comes that the product may be sold at a lower price.

Subsection $38(5)$ provides that these provisions dealing with suggested and advertised resale prices, (that is, subsections $38(3)$ and (4)) do not apply to a price that is affixed or applied to a product or its package or container. Thus, the practice of prepricing containers and packages is not affected by subsections $38(3)$ and (4).

A further amendment to the resale price maintenance provisions of the Act is contained in subsection $38(6)$, which provides that no person shall by any means whatever attempt to induce a supplier, as a condition of his doing business with the supplier, to refuse to supply a product to a particular person or class or persons because of the low pricing policy of that person or class of persons.

\section{F. Foreign Directives}

The Stage I amendments added new sections to the Combines Investigation Act, ${ }^{36}$ reflecting general concern as to the extraterritorial impact of foreign antitrust policy and legislation.

Section 31.5 applies where the implementation of a foreign judgment, decree or order in Canada would adversely affect competition in Canada or the efficiency of trade or industry in Canada, without bringing about or increasing in Canada competition that would restore and improve such efficiency or the foreign trade of Canada, without compensating advantages, or would otherwise restrain or injure trade or commerce in Canada without compensating advantages. In these circumstances, the Commission may order either that no measures be taken in Canada to implement the foreign judgment, or that measures be taken in such manner as the Commission may prescribe.

Section 31.6 applies where, (i) as a result of a foreign law or directive or "intimation of policy" or "other communication" to a person in Canada, a decision has been made or is about to be made in Canada which, if implemented, would be likely to have any of the effects mentioned in the foregoing paragraph with respect to foreign judgments, or (ii) a decision has been made or is about to be made as a result of a directive from a person in a country other than Canada, who is in a position to influence the policies of a person in Canada given for the purpose of implementing a conspiracy, combination, agreement or arrangement that if entered into in Canada would be in violation of section 32 of the Combines Investigation Act. Under these circumstances, the Commission may order either that no measures be taken in Canada to implement the law, directive, instruction, intimation of policy or other communication, or that measures be taken in such manner as the Commission may prescribe. 
Section 31.7 is designed to apply to situations where a supplier outside Canada refuses to supply a product or otherwise discriminates in the supply of a product to any person in Canada at the instance of, and by reason of the exertion of buying power outside Canada by another person. In these circumstances, the Commission may order any person to supply on equitable terms and conditions, or, in the alternative, not to deal or to cease to deal, in Canada, in such product of the the supplier.

\section{G. Other Stage I Amendments}

The Stage I amendments also introduced amended misleading advertising provisions, ${ }^{37}$ amended provisions in respect to tests and testimonials, 38 and new prohibitions against the practices referred to as "double ticketing",39 "pyramid selling",40 "referral selling",41 "bait and switch selling", 42 "sale above advertised price",43 and amended provisions relating to "promotional contests".44

\section{MERGERS AND MONOPOLIES}

The present provisions of the Combines Investigation Act relating to "mergers" have not as yet been amended, and await either the passage of Bill C-13 or the reintroduction, in legislative form, of the Stage II proposals.

Section 33 of the Combines Investigation Act simply states:

Every person who is a party to or privy to or knowingly assists in, or in the formation of a merger or monopoly is guilty of an indictable offence, and is liable to imprisonment for two years.

The term "merger" presently means the acquisition by one or more persons, whether by purchase or lease of shares or assets or otherwise, of any control over or interest in the whole or part of the business of a competitor, supplier, customer or any other person, whereby competition in trade, industry, or profession, among the sources of supply of a trade, industry or profession, among the outlets for sales of a trade, industry or profession, or otherwise, is or is likely to have lessened to the detriment or against the interest of the public, whether consumers, producers or others.

In the absence of legislative direction concerning the scope of the present merger provision, the meaning of the test as to whether "competition is or is likely to be lessened to the detriment of the public" must be obtained from judicial pronouncements.

The basic law in this area, as reviewed in the Canadian Breweries4s

37. Id. ss. 36(1) and 2.

38. Id. s. 36.1

39. Id. s. 36.2

40. Id. s. 36.3

41. Id. s. 36.4 .

42. Id. s. $37(2)$

43. Id. s. 37.1 .

44. Id. s. 37.2

45. $R$. v. Canadian Breweries Ltd. (1960) 126 C.C.C. 133, [1960] O.R. 601, 33 C.R. 1, 34 Can. Pat. R. 179. 
and B.C. Sugart6 cases, has recently been updated in the Supreme Court of Canada's 1976 decision in the K.C. Irving case.47

That case involved an allegation that K.C. Irving Ltd. and others were parties to the formation of a combine that was a merger, trust or monopoly by reason of the purchase or acquisition of control over certain newpapers in New Brunswick. Laskin C.J.C. noted:48

There is no doubt in this case that the Irving interests have such control of the English language newspapers in New Brunswick as to satisfy the opening parts of the definition of "merger" and "monopoly", and part of the definition of "merger, trust or monopoly". The question that remains in relation to the meaning of "merger" is whether, by reason of the acquisition of that control, "competition is or is likely to be lessened to the detriment or against the interest of the public; and in relation to the meaning or "monopoly" and of "merger, trust or monopoly" whether the person or persons having such control "have operated or are likely to operate (the controlled business) to the detriment or against the in terest of the public.

The statutory prerequisites to a conviction necessitated proof of detriment. Laskin C.J.C. was prepared to hold that it could not be concluded simply on proof that one company obtained control of all other companies in an industry in a particular region that a "combine" as defined in section 32(1) or a "merger" or "monopoly" existed. There is, in addition, a heavy onus on the Crown to adduce direct proof of this element of "detriment", and in the absence of proof no "detriment in law" may be presumed to exist.

The setting aside of the conviction in the K.C. Irving decision established, from the viewpoint of the Crown, the inadequacies of the criminal law in dealing with "mergers". It led to the Skeoch McDonald recommendation (echoing the earlier conclusions of the Economic Council) that mergers should be viewed and dealt with as civil matters reviewable by a special quasi-judicial tribunal.

The advantage to the Crown of such an amendment would be the elimination of the heavy criminal standard of proof beyond a reasonable doubt and the application of balance of probabilities considerations, thus removing many of the judicially imposed restrictions which surround the application of the existing section 33 .

\section{REGULATED CONDUCT EXEMPTION}

In addition to the significant uncertainties which surround the potential application of various provisions of the Combines Investigation Act, and, in particular the merger and monopoly sections, it is useful to recognize the existence of a basic jurisdictional issue as to whether the provisions of the Combines Investigation Act apply to various forms of corporate activity in the resource sector which are already subject to direct provincial regulatory authority.

\section{A. An Industry Overview}

The exploration for and development of natural resources in Canada in general, and of oil and gas in particular, is one of the most highly

46. $R$. v. British Columbia Sugar Refining Co. Ltd. (1960) 129 C.C.C. T. 36 C.R. 32,38 Can. Pat. R. 177, 32 W.W.R. 577.

47. R. v. K. C. Irving et. al. (1976) C.C.C. 1, 12 N.B.R. 259.

48. Id. at 16. 
regulated forms of business activity in Canada. Moreover, recent ventures into the Beaufort Sea, into secondary and tertiary recovery methods, and into tar sands and similar projects, are subject to the closest form of provincial regulatory scrutiny.

Many of these projects have traditionally developed through the use of the "joint venture" as an essential mechanism for facilitating high cost and high risk activities. This vehicle continues to be a cornerstone of resource related activity today.

The physical and financial resources of industry are not unlimited. Through the co-operative sharing of cost and risk to acquire and operate lands, drill wells, develop and jointly operate oil and gas plants, transport oil and gas, and more recently develop the tar sands, substantial advances have been made on a larger scale than might otherwise be possible.

It is recognized that any one of many producing companies could undertake the operation of a gas plant, the construction of a pipeline or the drilling of a well on its own account. However, it continues to be the view ${ }^{49}$ that the most efficient and economic use of capital in the interests of all parties, including the consumer, dictates that a group approach often be employed. Additionally, the wide range of investment activity available to the smaller producer would be curtailed in the absence of "joint venture" arrangements designed to spread substantial risk and cost factors.

The "joint venture" mechanism, in many forms, may be shown to be procompetitive, and provides direct capability for both large and small producers to share risks, costs, revenues, and increase efficiencies. The various provincial regulatory authorities have recognized this fact, and have acted accordingly.

In the Province of Alberta, for example, The Oil and Gas Conservation Actso has a direct regulatory impact on the manner in which wells are to be drilled and product obtained. The principal object of that legislation is: ${ }^{31}$

(a) to effect the conservation of, and to prevent the waste of, the oil, gas and crude bitumen resources of Alberta,

(b) to secure the observance of safe and efficient practices in the locating, spacing, drilling, equipping, completing, reworking, testing, operating and abandonment of wells and in operations for the production of oil, gas and crude bitumen.

(c) to afford each owner the opportunity of obtaining his share of the production of oil or gas from any pool or of crude bitumen from any oil sands deposit.

(d) to provide for the recording and the timely and useful dissemination of information regarding the oil, gas and crude bitumen resources of Alerta, and

(e) to control pollution above, at or below the surface in the drilling of wells and in operations for the production of oil, gas and crude bitumen and in other operations over which the Board has jurisdiction.

The manner of "affording each owner the opportunity of obtaining his share of oil or gas from any pool or of crude bitumen from any oil

49. Cf. Canadian Petroleum Association. Submission to the Standing Senate Committee on Banking, Trade \& Commerce Respecting Bill C-42, reported in Proceedings of the Standing Senate Committee on Banking, Trade \& Commerce, No. 22, Feb. 23, 1978 at 22:25.

50. R.S.A. 1970, 267 as amended.

51. Id. s. 5 . 
sands deposit" has traditionally involved such considerations as spacing, unitization, controlling rates of production, etc.

Part 12 of the legislation, dealing with "Unit Operation", contains a mandate to the Energy Resources Conservation Board, directing that's2

The Board shall encourage efforts initiated by owners of oil and gas interests in any pool to consolidate, merge or otherwise combine their interests for the purpose of accomplishing the more efficient and more economical development and production of the oil and gas resources of the pool, irrespective of whether that purpose is accomplished by unit operation, co-operative development or joint participation.

The Oil and Gas Conservation Act may be "the cornerstone" of the legislative structure, but it is only one part of an extensive network of legislative and regulatory sanctions which have been validly imposed by provincial authorities on the physical operation of the oil and gas industry.

In response, therefore, to industry preferences for efficient capital cost and risk allocation and provincial regulatory mandate, sophisticated mechanisms have evolved, such as the Farmin, Farmout, Joint Operating Agreement, Unit Agreement and Pooling Agreement.

In addition to these forms of "joint ventures" in the unincorporated form, there are examples of incorporated "joint ventures". These are often organized and financed largely by producers, such as Syncrude Canada Ltd., Cansulex Limited and Sultran Ltd., and play a vital and expanding role in meeting Canadian energy needs.ss

B. Regina v. Canadian Breweries Reviewed

The extent of provincial jurisdiction and regulatory mandate over "joint venture" activity raises a basic issue as to the application or non-application of the Combines Investigation Act itself to such activities.

The leading case of Regina v. Canadian Breweries Limiteds4 established, inter alia, that where a product is subject to control and regulation by the legislative jurisdiction of a provincial regulatory commission or board, and where such commission or board had duly exercised that power in the public interest, a Court must assume that the power has been exercised in the public interest.

In that decision McRuer, C.J.H.C. noted at 630:

When a provincial legislature has conferred on a commission or board the power to regulate an industry and fix prices, and the' power has been exercised, the Court must assume that the power is exercised in the public interest. In such cases, in order to succeed in a prosecution laid under the Act with respect to the operation of a combine, I think it must be shown that the combine has operated, or is likely to operate, so as to hinder or prevent the provincial body from effectively exercising the powers given to it to protect the public interest. If the evidence shows that by reason of a merger the accused is given a substantial monopoly in the market, this onus, in my opinion, would be discharged.

There may, however, be areas of competition in the market that are not affected by the exercise of the powers conferred on the provincial body in which restraints on competition may render the operations of the combine illegal.

52. Id. s. 81(1).

53. The legal characterization of a "joint venture", as distinct from a partnership, cotenancy, joint-tenancy, etc. is reviewed in Olisa, Legal Problems Arising Out of Co-ownership of Oil \& Gas Leasehold Estates and Facilities (1970) 8 Alta. L. Rev. 177.

54. Supra, n. 45. 
It is recognized that to the extent joint activities are subject to express regulation by provincial authority, the Combines Act does not apply. ${ }^{55}$ Conversely, commercial activity not "effectively regulated" by a public authority would appear to be subject to the Combines Investigation Act.

The issue was squarely addressed in a lecture some years ago by D.H.W. Henry, Q.C. (as he then was); his interpretation of the decision, as Director of Investigation and Research, was stated as follows: ${ }^{56}$

For the purposes of administering the Act, I regard this decision as one which stands for the proposition that where government controls are imposed upon an industry, so that the authorities become the regulator of industry in the public interest, then, the Combines Investigation Act, which is designed to ensure that competition shall be the regulator of industry in the absence of such controls does not ordinarlly have application.

The law, as set out in the Canadian Breweries case and the Farm Products Marketing Act case, leaves substantial doubt as to the precise extent of the exemption from the Combines Investigation Act where provincial legislation has "expressly required" or "expressly authorized" a specific joint venture activity.

The Senate Standing Committee on Banking, Trade and Commerce dealt with this particular area in its report on Bill C-2. It stated that clarification was required so that no industry, trade or profession, the bulk of whose activities are already regulated by a provincial or federal governmental body, should also be subject to prosecution under the Combines Investigation Act. The Committee concluded:57

Your committee favours a solution whereby the particular regulatory body concerned is responsible for all matters with respect to the industry under its jurisdiction to the exclusion of the Combines Investigation Act.

In the absence of careful clarification and effective legislative response to that recommendation, the full extent of the exemption remains unclear.

\section{STAGE II AMENDMENTS: BILL C-13}

The July, 1973 decision to divide the reform of Canadian competition policy into two stages deferred, for a time, the debate concerning a number of critical areas of competition policy.

In the spring of 1975 the Minister of Consumer and Corporate Affairs requested a group from the private sector to consider the areas of "mergers", "monopolization", "price discrimination", "loss leader selling", "rationalization", "export agreements" and "interlocking directorates". The Skeoch-McDonald Report was prepared and submitted with respect to these matters on March $31,1976 .{ }^{38}$

Bill C-42 was subsequently introduced into the House of Commons on March 16, 1977, and dealt, inter alia, with mergers, monopoly,

55. See also Reference Re Farm Products Marketing Act (1957) 7 D.L.R. (2d) 257, [1957] S.C.R. 198.

56. Henry, Unfair Distribution and Pricing Practices (1963) Law Society of Upper Canada Special Lectures 1.

57. Reporting of the Standing Senate Committee on Banking. Trade \& Commerce Respecting Bill C-2, (1975) Sen. Deb. No. II 1589 at 1591.

58. Cf. Skeoch and McDonald, Dymamic Change and Accountability in a Canadian Market Economy ii (1976). 
monopolization, export (and import) agreements, price discrimination, abuse of intellectual property and certain so-called civil reviewable matters.

In addition, there were a number of new departures introduced in the areas of joint monopolization, specialization agreements, price differentiation, systematic delivered pricing, and class and substitute actions.

The Canadian Petroleum Association appeared as one of a number of interested parties before the House of Commons Standing Committee on Finance, Trade and Economic Affairs, and Commerce in the Summer of 177; and, following minor and inconsequential amendments, Bill C-42 was reintroduced and received first reading on November 18, 1977, as Bill C-13.

Bill C-13, through the operation of the so-called "Hayden formula" for direct referral of legislation to the Senate, as of this date continues to be under close review by the Standing Senate Committee on Banking, Trade and Commerce.

In introducing the Bill, Consumer and Corporate Affairs Minister Warren Allmand maintained that the revisions were in keeping with the Government's original undertaking to respond to constructive proposals for strengthening and improving the legislation. However, from the point of view of the petroleum resource sector, with minor exceptions, it was necessary to record our continuing concern that the cumulative effect of many of the legislative initiatives proposed would be to significantly prevent the development of the kind of economy which could readily adapt to changing Canadian circumstances.

It is now proposed to look at certain aspects of the Bill in detail.

A. Administrative Provisions:

Machinery and Procedures

The machinery and procedures proposed under Bill C-13 for the administration of competition policy are materially different from the present law.

The existing Combines Investigation Act, known by that title since 1910, would be renamed the "Competition Act", or "An Act to provide for the general regulation of trade and commerce by promoting competition and the integrity of the marketplace, and to establish a Competition Board and the office of Competition Policy Advocate". This would reflect the wider scope of application of legislation.

The preamble to Bill $\mathrm{C}-13$ reviews those goals which are central to Canadian economic policy and recognizes:

(i) a central purpose of Canadian public policy is to promote the national interest and the interest of individual Canadians by providing an economic environment that is conducive to the efficient allocation and utilization of society's resources, fosters innovation in technology and organization, expands opportunities relating to both domestic and export markets, and encourages the transmission of those benefits to society in an equitable manner;

(ii) one of the basic conditions requisite to the achievement of that purpose is the creation and maintenance of a flexible, adaptable and dynamic Canadian economy that will facilitate the movement of talents and resources in response to market incentives, that will reduce or remove barriers to such mobility, except where such barriers may be inherent in economies of scale or in the achievement of other savings of resources, and that will protect freedom of economic opportunity and choice by discouraging unnecessary concentration and the predatory exercise of economic power and by reducing the need for detailed price regulation of economic activity: 
(iii) the effective functioning of such a market economy may only be ensured through the recognition and encouragement of the role of competition in the Canadian economy as a matter of national policy by means of the enactment of general laws of general application throughout Canada and by the administration of such laws in a consistent and uniform manner.

Fundamental to the attainment of the above-noted objectives are the proposed functions for the new office of the Competition Policy Advocate and the Competition Board.

\section{B. The Competition Policy Advocate}

It is proposed that the present Director of Investigation and Research under the Combines Investigation Act will be known as the Competition Policy Advocate. This alteration would recognize the new and expanded role which such office will be expected to perform in respect to a wide and all encompassing range of business activity, including a stronger role as intervenor before federal regulatory agencies.

In addition to traditionally recognized research and reporting functions, the Advocate will serve as general spokesman on behalf of the maintenance of competition..$^{59}$

Currently, pursuant to the provisions of Section 27.1 of the Combines Investigation Act, the Director of Investigation and Research,60

at the request of any federal board, commission or other tribunal or upon his own initiative, may, and upon direction from the Minister shall, make representations to and call evidence before any such board, commission or other tribunal in respect of the maintenance of competition, whenever such representations or evidence are relevant to matter before the board, commission or other tribunal, and to the factors that the board, commission or other tribunal is entitled to take into consideration in determining such matter.

For the purposes of Section 27.1 "federal board, commission or other tribunal" means any board, commission, tribunal or person expressly charged by or pursuant to an enactment of Parliament with the responsibility of making decisions or recommendations related directly or indirectly to the production, supply, acquisition or distribution of a product". This would include an ad hoc commission of inquiry charged with any such responsibility, but does not include a court.

Bill C-13 envisages an expanded role for the Competition Policy Advocate. It is presently proposed that the Adyocate be able to make representations in respect of any of the central purposes of Canadian public policy as expressed in the preamble, and may appeal or obtain a review of any such decision as if he were a party aggrieved or otherwise affected by the decision.

The Government's intentions in this area are expressed in the Annual Report of the Director of Investigation and Research for the Year Ended March 31, 1977:61

In the Stage II amendments, now in the legislative process, the responsibilities and duties of the Director (to become the Competition Policy Advocate) in this connection are expanded, and more stringent conditions are required to be met before a regulated group, whether federal or provincial, may be exempted from the prohibitions of the Act.

59. An Act to amend the Combines Investigation Act and to amend the Bank Act and other Acts in relation thereto or in consequence thereof, 3rd Sess. 30th Parl., 1977. Bill C-13, ss. 27.1(1) and (2) (H. of C.).

60. See Annual Report of the Director of Investigation and Research for the Year Ended March S1, 1977, 9.

61. Id. 
As indicated above, the common law is unclear as to when provincially "regulated" conduct is not subject to the Act. This difficulty remains in the proposed legislation because, from a drafting point of view, the definition of "regulated conduct" is inadequate.

The proposed definition for "Regulated Conduct" reads as follows:62

Conduct that has been expressly required or authorized by a regulating agency that is not appointed or elected by the persons, or by classes or representatives of the persons, whose conduct is subject to be regulated by such agency, or is subject to supervision in the case of a regulating agency that is an agricultural products marketing board, by a supervising agency that is not appointed or elected by the persons, or by classes or representatives of the person, whose conduct is subject to be regulated by such regulating agency. In addition, the regulating agency must be expressly empowered, by or pursuant, to an Act of Parliament or of the legislature of a province, to regulate the conduct in the manner in which it is being regulated and has expressly directed its attention to the regulation of the conduct.

The Senate recommended that the definition of "regulated conduct" be amended so that "any conduct authorized by a 'public agency' by or pursuant to an Act of Parliament or of the legislature of a province or which is subject to review by such agency, and the agency has not disapproved within the time limits, if any, provided in the law in question should be exempt from the application of the Act."63 That recommendation was not carried forward.

In the course of providing legal opinions to our clients we will be obliged to consider whether conduct is "expressly" subject to the regulating agency, or whether an agency has "expressly" directed its attention to a given action or activity. The fact that the general authority in Boards and Agencies to act may have indirectly prompted certain forms of activity may lead the Advocate to the erroneous view that a given action was not the subject of "direct attention" by the regulator and, therefore, make the Act applicable where heretofore it had not been applied.

The highly subjective nature of legislation of this type has necessitated that provision, albeit limited, be made for the Advocate to provide "interpretive opinions". Bill C-13 stipulates64 that the Advocate may issue an interpretive ruling setting out the interpretation he places on a word or combination of words in the Act; such ruling is binding on him unless changed by the Board or the Court.

\section{The Competition Board}

It is proposed that the existing Restrictive Trade Practices Commission, currently consisting of four members, be replaced by a Competition Board consisting of seven permanent and five associate members. They will act in a quasi-judicial manner and assume responsibility for the civil review process, for the exercise of wide-ranging powers to issue directory, prohibitory and dissolution orders and provide forms of injunctive relief. The responsibilities of the Restrictive Trade Practices Commission respecting investigations and research inquiries will now be the direct responsibility of the Competition Policy Advocate.

62. Bill C-13, supra n. 59, s. 4.5(2).

63. Senate of Canada, Interim Report of the Standing Committee on Banking. Trade \& Commerce Respecting Bill C.42. Proceedings of the Standing Senate Committee on Banking, Trade \& Commerce, No. 48, July 6, 1977, at 15-16.

64. Bill C.13, supra n. 59, s. 27.2 .

65. Id. ss. 27.2(2) and (4). 
The Competition Board is to be established as a court of record.66 However, it is proposed that such tribunal not be bound by any legal or technical rules of evidence. Section 31.8(4) provides for the general right of the Attorney General of a Province to intervene in proceedings before the Board; and Section 31.78 provides that where the Board is of the opinion that a person other than the applicant is likely to be substantially affected by any order the Board might make or that such person is likely to contribute materially to the resolution of an issue before the Board, an opportunity to be heard will be provided.

\section{Reviewable Matters}

The Competition Board, upon application by the Competition Policy Advocate (or in the case of a specialization agreement, any party to such agreement) after affording the parties an opportunity to be heard, will be empowered to issue remedial orders respecting the practices discussed below.

\section{1) Mergers}

\section{The Senior Deputy Director recently stated:67}

The single most important substantive measure in the Bill is Section 31.71 dealing with mergers. It is in this area that most glaring weakness of the present law exists.

The K.C. Irving decision prompted the Government to recommend the movement of the existing Combines Investigation Act section relating to mergers from the present criminal law area to the civil law area, making the offence a reviewable practice, and replacing the heavy criminal standard of "proof beyond reasonable doubt" with the civil "balance of probabilities test".

In the event that the Advocate believes that grounds exist for making an order, he could apply, under this section, to the Competition Board. The Board may sit as a panel of three, one of whom will be a permanent member of the Board.

The definition of "merger", amended from that proposed in Bill C-42, is found in proposed Section 31.71. It states that for the purposes of the Act,

merger means any acquisition or establishment by one or more persons, whether by purchase or lease of shares or assets, by amalgamation or in any similar manner, of any control over or interest in the whole or any part of the business or a competitor, supplier, customer or any other person and includes a joint venture that is effected or to be effected by the creation of a corporation.

Section 31.71 is stated to apply: 68

to a merger that has not been completed before the coming into force of this section, that lessens or is likely to lessen, substantially, actual or potential competition

(a) in a trade, industry or profession,

(b) among the sources from which a trade, industry or profession obtains a product,

(c) among the outlets through which a trade, industry or profession disposes of a product, or

(d) otherwise than as described in paragraphs (a) to (c),

and that, in the case of a horizontal merger, results or would be likely to result in the combined share of the merged persons and their affiliates immediately following the merger exceeding twenty per cent of any market.

66. Id. s. 31.8 .

67. An Overview of Stage II Amendments in Stanbury, Papers on Bill C-19, The Proposed Competition Act, prepared for the seminar "Canadian Competition Policy: The Stage II Amendments to the Combines Investigation Act" held in Vancouver, B.C. on Nov. $29,1977$.

68. Bill C-13, supra n. 59, s. 31.71(1). 
It is further provided that 69 if, upon application by the Competition Policy Advocate, the Board finds that any such person has been or is about to be party to a merger to which this section applies, the Board may, subject to subsection (5), make an order directing that person to dissolve the merger or dispose of assets designed by the Board in such manner as the Board prescribes, or direct him not to proceed with the merger, as the case may be.

It is submitted that the inadequacies of both the case law and the regulated conduct exemption, and of the proposed section itself raise a number of significant uncertainties.

A central problem is the explicit recognition and inclusion of "joint ventures" effected by the creation of a corporation within the definition of "merger", and the change in the definition to include activities which constitute the establishment of any control over or interest in the business of a competitor, supplier, customer or any other person, whether by purchase or lease of shares or assets, by "amalgamation, or in any similar manner". The definition would not effectively exclude unincorporated joint ventures. Additionally, the term "amalgamation" is not defined, and there is precedent for the proposition that the word had no precise meaning 70 in any strict legal sense.

Accordingly, the bringing together, consolidating, grouping or amalgamating of physical or intangible assets or interests in the context of joint venture activity, whether in the form of an unincorporated or incorporated joint venture activity, may well be viewed as a "merger" for the purposes of the proposed Act. This raises concern as to whether the section might apply to joint operating agreements, joint venture exploration agreements, voluntary pooling agreements, or to large scale corporate joint ventures.

The Interim Report of the Standing Senate Committee on Banking, Trade and Commerce recognized the significance of the concern and concluded:"1

The definition of 'merger' contained in proposed section $\mathbf{3 1 . 7 1}$ is broad enough to include joint ventures, or, consortia, as they are sometimes called. This will have the effect of discouraging many projects in Canada which, because of the magnitude of investment required, technological problems or other considerations, can only be accomplished by several or oven all of the firms in a given industry combining on a co-operative basis. Your Committee recommends that an exemption be granted for joint ventures which meet these criteria. The exemption should apply notwithstanding that the parties may choose to operate the venture through a corporation the shares of which are owned by them.

Representations also have been made by various representatives of resource industries that the particular wording of Section 31.71 which defines mergers would include many forms of activities which have evolved in a natural way for the expeditious exploration, development, extraction and distribution of natural resources. These forms include joint ventures, joint bidding, 'farm-out' and 'farm-in' agreements, joint operating agreements, unitization agree. ments and common asset ownerships, most of which result from or are subject to direct government input and regulation.

The seriousness of the disruption of industry which would result from the application of the proposed amendment, it is claimed, is such as to prejudice and jeopardize the resource industries generally and the oil and gas exploration and development industry in particular. It is claimed that the inclusion of joint ventures within the scope of the merger provisions would introduce an air of uncertainty which detracts from the ability to carry on operations

69. Id. s. 31.71(3).

70. Cf. Wall v. Northern Assets Corp. [1898] 2 Ch. 469.

71. Senate of Canada, supra n. 63, Appendix at 8. 
effectively; equally, it was represented to your Committee by the Canadian Petroleum Association in their brief on page iv of its summary, that the monopoly and joint monopolization sections of the Bill may effectively prohibit oil and gas exploration and production operations as presently carried out.

At a time when the Minister of Energy is engaged in instituting incentives to promote development of new energy resources, it appears to your Committee that disruptive and unsettling legislation of the type contemplated by the amendments concerning mergers, joint ventures, monopolization and joint monopolization should not be considered by Parliament.

Your Committee recommends that adequate exemptions be provided for joint ventures in the resource industries in such a manner as would not discourage or disturb their further and continued development.

Bill C-13 details some fourteen factors which the Competition Board may consider together with "any other factor which is relevant to competition in a market affected by the merger" in deciding whether it will direct the person to dissolve the merger or dispose of assets in a manner to be prescribed, or direct the parties not to proceed.72 The Board is precluded from making an order if it finds that there is a clear probability that such merger will bring about substantial gains in efficiency that save resources for the Canadian economy.

The uncertainties surrounding the precise application of the section to specific "merger" cases were considered by both the House and Senate Committee. Provision was made 7 in Bill C-13 for the issuance of "a certificate" which has been referred to as a "preclearance"; but in fact the procedure may prove to be nothing more than an informal assurance which is not administratively binding.

This is due to Section 7 of the existing Combines Investigation Act which continues to permit six resident persons to apply for an inquiry, and Section 8(c) of the existing Act which requires the Director to cause an inquiry to be made whenever such action is directed by the Minister. Either section could lead to the imposition of the severe sanctions mentioned earlier, and lessen the value of the clearance procedure and certificate presently proposed.

If one of the parties to a merger notifies the Competition Policy Advocate of the merger, the Competition Policy Advocate is precluded from making an application 74 to the Board for an order in respect of the merger upon the expiration of six months after receipt by him of such notification or additional information unless there was a failure to disclose material facts or unless the period is extended upon application to a member of the Competition Board. Therefore, in the event that the referral is not made, it would appear that the merger would be reviewable at any time without time limitation.

\section{2) Mergers and the Foreign Investment Review Act}

The draftsmen of both Bill C-42 and Bill C-13 have had to develop a functional interrelationship between F.I.R.A. and combines matters in the "merger" area, which, if implemented, will raise further procedural and timing restraints.

72. Bill C-13, supra n. 59, s. 31.71(4).

73. Id. s. 31.71(19).

74. Id. ss. 31.71(22) and (23). 
Under the provisions of Bill C-1375 there is a direct obligation on F.I.R.A. to provide the Competition Policy Advocate with a copy of the notice of an investment under F.I.R.A., together with a copy of all written undertakings, information and representations submitted or given to the Minister.76

In the case of a "non-eligible person", as defined in the Foreign Investment Review Act," who may intend to acquire control of a Canadian business enterprise, "whether by purchase or lease of shares or assets, by amalgamation, or in any similar manner, of any control over or interest in part of the business of a competitor, supplier or customer, or any other person", a direct form of further government review has been imposed. If implemented, this could materially inhibit desirable corporate mergers and acquisitions in the resource sector.

The Competition Policy Advocate has a period of fifty days from the date on which he is notified of an investment under the Foreign Investment Review Act to certify to F.I.R.A. that he has made or intends to make an inquiry pursuant to Section 8 of the proposed Competition Act.

The receipt of the Certificate negates the effect of Section 13 of the Foreign Investment Review Act with respect to deemed allowance, and precludes any recommendation that the investment be allowed by the Governor in Council until such time as the matter is resolved.

The Canadian Petroleum Association has expressed its concern that following the certification to the Foreign Investment Review Agency by the Competition Policy Advocate of his intention to make an application, the Competition Policy Advocate is not bound to take any further action. The time delays will clearly not be acceptable to a vendor. Accordingly, citing the precedent in the Anti-Dumping Act, $1968-69,78$ it was recommended that at the very least a final determination of the matter ought to be made within a prescribed time. ${ }^{99}$ Similarly, insofar as the merger notification procedures are concerned,80 it was recommended that a restriction be placed upon the Competition Policy Advocate to restrain any further action he might take upon the expiration of sixty days after receipt of notification of the merger or additional information which may have been requested.

In the absence of effective amendment, and assuming the continued existence of the Foreign Investment Review Act, the acquisition of shares or assets by non-eligible persons could be discouraged, with the result that aggressive exploration and development plans may be materially affected.

3) Monopolization

The concept of "monopoly" will continue to be a reviewable trade practice both as a civil matter and as a criminal matter. This proposal reflects recognition of the fact that some practices will definitely not

75. Id. s. 31.71(9).

76. Id. s. 31.71(10).

77. S.C. $1973-74$, c. 46 , as amended.

78. R.S.C. 1970 , c. A-15, as amended.

79. Canadian Petroleum Association Brief Respecting Bill C-1S, 8.

80. Bill C-13, supra n. 59, s. 14(2)(d). 
be in the public interest, while others may or may not be depending on the circumstances.

The result proposed is to give the Competition Policy Advocate the choice between utilizing either civil or criminal proceedings.

"Monopoly" is defined in Bill C-13 as a situation where ${ }^{81}$ one person, or two or more persons who are affiliated with the meaning of the section, have sought or are seeking substantial control, throughout Canada for any area thereof, of a class or species of business in which they are engaged, or have sought or are seeking to entrench such control or to extend monopoly power into another market, by any behaviour or conduct that has or is likely to have the effect of restricting entry into a market, foreclosing to a competitor sources from which he might obtain a product or outlets through which he might dispose of a product, eliminating a competitor by predatory pricing, whether or not based on cross-subsidization, or by narrowing the margin between the cost to a customer and the price the customer can obtain in the market where the customer is also a competitor, or by any other predatory practice. In addition, it would include directly or indirectly coercing a competitor into avoiding, abandoning or restricting competitive behaviour or punishing such competitor for past competitive behaviour, or otherwise disciplining him, or restraining competition in any exclusionary or predatory manner similar to but other than a manner described, or any behaviour or conduct the effect of which would afford a basis for an order by the Board under any other provision of the Part of the Act, or would constitute a contravention of any provision of Part V or Section 46.1 of the Act.

Following application by the Competition Policy Advocate, if the Board finds that a person has been a party to a monopolization, 82 an order may be made directed to any person who has been afforded an opportunity to be heard prohibiting him from engaging or continuing to engage in any behaviour or conduct specified in the order that the Board finds to have had or to be likely to have any one or more of the effects described, or directing him to take such action as the Board considers necessary to overcome the effects of any such behaviour or conduct or to stimulate or restore competition that has been impaired by such behaviour or conduct. Where the Board finds that a remedy described above will not suffice to stimulate or restore in any relevant market competition that has been impaired by any such behaviour or conduct, it may direct him to divest himself of such part of his business or assets as is prescribed in the order, in a manner prescribed therein.

It is further provided that one or more persons may have substantial controles of a class or species of business notwithstanding that they account for less than fifty per cent of such class or species of business, if that person or persons taken together dominate that class or species of business in a relevant market.

Limitations to the application of the section will apply if criminal

81. Id. s. 31.72(1).

82. Id. s. 31.72(3).

83. Id. s. 31.72(2). 
proceedings have been instituted,84 or if the Board finds that the impugned behaviour or conduct clearly reflects superior economic efficiency or superior economic performance.

The section raises the issue whether joint operations or joint ventures which are not subject to direct provincial regulatory authority, and which are designed for the efficient promotion of exploration and production, might be viewed as constituting group behaviour that "has or is likely to have the effect of restraining economic activity in any exclusionary or predatory manner". 85

The government response has traditionally been that it is not the Bureau's intention to destroy time honoured methods by which companies participate in joint exploration ventures. In fact statements appear to recognize that the traditional system has generally worked in favour of Canada's economic interests, and that joint venture operations are inherently pro-competitive.

It is the Canadian Petroleum Association's view ${ }^{86}$ that the potential application or non-application of the criminal or civil monopoly provision should be capable of determination not on the basis of government assurances, but on the basis of clearly drafted legislation which can be precisely interpreted.

\section{4) Joint Monopolization}

The most controversial and inappropriate aspect of the proposed new reviewable matters relates to "joint monopolization".

The expression is defined in Bill C-13 $3^{37}$ to mean a situation where a small number of persons, not all of whom are affiliated within the meaning of the legislation, achieve substantial control or entrench such control throughout Canada or any area thereof over a class or species of business in which they are engaged by adopting closely parallel policies or closely matching conduct of an exclusionary character, which policies have or conduct has the effect of restricting entry into a market; foreclosing to a competitor sources from which he might obtain a product or outlets through which he might dispose of a product; eliminating a competitor by predatory pricing, whether or not based on cross-subsidization, or by narrowing the margin between the cost to a customer and the price the customer can obtain in the market where the customer is also a competitor, or by any other predatory practice; directly or indirectly coercing a competitor into avoiding, abandoning or restricting competitive behaviour, or punishing him for past competitive behaviour, or otherwise disciplining him, or restraining competition in any exclusionary or predatory manner similar to but other than a manner described.

The Bill further provides that where, on application by the Compettion Policy Advocate, and after affording every person against whom an order is sought a reasonable opportunity to be heard, the Board finds that a person has been a party to a joint monopolization, the

84. Combines Investigation Act, n. 1, s. 33.

85. Bill C-13, supra n. 59, s. 31.72(1).

86. See Proceedings of the Standing Senate Committee on Banking, Trade \& Commerce, Feb. 23, 1978, 22:25.

87. Bill C-13, supra n. 59, s. 31.73 . 
Board may make an order directed to any person who has been so afforded an opportunity to be heard prohibiting him from engaging or continuing to engage in any policies or conduct specified in the order that the Board finds to have had or to be likely to have one or more of the effects described in the section, or directing him to take such action as the Board considers necessary to overcome the effects of such policies or conduct or to stimulate or restore competition that has been impaired by such policies or conduct; or where the Board finds that these remedies will not suffice to stimulate or restore, in any relevant market, competition that has been impaired by any such policies or conduct, it may direct him to divest himself of such part of his business or assets as is prescribed in the order in a manner prescribed therein.

Additonally, and most significantly, a proposed sectiones introduces the concept of "conscious parallelism" into Canadian law by providing that "a small number of persons may be found to be engaging in joint monopolization notwithstanding that the parallel policies or matching conduct adopted by them involved no agreement or arrangement between or among them".

This provision clearly requires careful reconsideration from many perspectives. From a theoretical viewpoint, it assumes that there is a direct correlation between industrial concentration and lack of market discipline. The realities of oligopolistic behaviour in our industry are largely ignored in favour of a more academic approach which, if implemented, will lead to severe price rigidities in the marketing sector.

It has been submitted thates the theory behind the section, that uniformity of conduct within oligopolistic sectors of Candian industry infers an absence of competition and is inherently objectionable, cannot be justified.

The Canadian petroleum industry, being both capital and risk intensive, is oligopolistic in nature. It is characterized by the presence of relatively few large producers who are faced with similar cost structures and who market products substantially similar in nature and, therefore, easily substituted by a consumer in the event of price differences.

In the context of this economic fact, there is often a "price leader", which is generally the most efficient operator in any given market area. The "price leader" may be any one of the petroleum marketers, depending on the area, processing or logistical advantages. Because of such advantages the price leader may earn a better return than its competitors at any given price level. When the price leader is faced with significantly increased costs due to such factors as a crude oil price or labour settlement, it must raise prices to maintain its return on investment. The smaller companies, usually with a lower return but similar cost increases, cannot forego the opportunity to improve their lot by increasing their prices by a similar amount to the leader. In different markets and at different times, dependent on their relative strength in a particular market, different companies may attempt

88. Id. s. 31.73(6).

89. See Canadian Petroleum Association Submission Respecting Bill C-42, supra n. 49. 
to initiate price changes. In some circumstances others will react, and in some cases they will not. Rarely can a competitor risk charging more than the leader in that market for fear of losing business to the leader. The situation is further compounded in today's marketplace by the considerable government regulation, as to price and otherwise, which exists. But in no way does a situation in which price leadership exists mean there is an absence of price competition.90

The Senate Standing Committee on Banking, Trade and Commerce concluded, with respect to joint monopolization, as follows: 91

\begin{abstract}
All parties who appeared before your Committee were concerned about this new provision particularly because intent to harm does not appear to be an ingredient. If the parallel policies have certain effects, then the practice exists and is subject to orders by the Competition Board including divestiture. The provision is intended to apply even though the parallel policies were based on nothing more than a mutual recognition by the parties of their interdependence and that there was no agreement or arrangement between or among them. In other words, a perfectly natural situation achieved through innocent conduct may find itself in the inexorable grip of a criminal prohibition.
\end{abstract}

\title{
5) Intellectual and Industrial Property
}

In the area of intellectual and industrial property rights, it is proposed that the Competition Board possess new and expanded authority.

The proposal is that 92 where, on application by the Competition Policy Advocate, and after affording every person against whom an order is sought a reasonable opportunity to be heard, the Board finds that a person or persons, by exercising any right or interest, whether conferred by statute or otherwise, in a patent, trade mark, copyright or industrial design in a manner not expressly authorized by the Patent Act,93 the Trade Marks Act,94 the Copyright Act,93 or the Industrial Design Act, 96 as the case may be, have affected or are likely to affect competition adversely in a market, the Board may make an an order directed to any person who has been afforded an opportunity to be heard declaring unenforceable, in whole or in part, any agreement, arrangement or licence into which that person has entered relating to the use of the patent, trade mark, copyright or industrial design; restraining that person from carrying out or exercising any or all of the terms and provisions of an agreement, arrangement or licence mentioned above, or directing the granting by that person of licences under the patent, copyright or industrial design to such persons and on such terms and conditions as are specified in the order.

\section{6) Orders in Respect to Interlocking Management}

Section 31.75 would apply to the case where the Board finds that a person is a director or officer of each of two or more corporations,

90. It is noted that recent submissions to the Bryce Commission on Corporate Concentration in Canada have indicated that there is no justification for the view that industrial concentration serves to free up firms from effective market discipline.

91. Supre n. 63 at $30-1$.

92. Bill C-13, supra n. 59, s. 31.74(1).

93. R.S.C. 1970, C. P-4, as amended.

94. R.S.C. 1970, C. T-10, as amended.

95. R.S.C. 1970, C. C-30, as amended.

96. R.S.C. 1970, C. I-8, as amended. 
or a person holds an office mentioned above in one or more corporations and the other office mentioned above in one or more other corporations. If the Board also finds that competition in the production or supply of a product in or to any market is likely to be thereby substantially lessened, or that sources of supply or outlets for sales are or are likely to be thereby foreclosed to competitors of those corporations, it may make an order directed to that person prohibiting him from continuing to hold any such office in more than one of the corporations, or in more than such of the corporations as are named in the order.

\section{7) Specialization Agreements}

Section 31.76(1) of Bill C-13 defines the term "specialization agreement" to mean an agreement in which each party agrees to discontinue producing an article in the production of which he is engaged at the time the agreement is entered into on the condition that each other party to the agreement agrees to discontinue producing an article in the production of which he is engaged at the time the agreement is entered into, and includes such an agreement in which the parties also agree to buy exclusively from each other the articles that are the subject of the agreement.

It is further provided that where, on application by any person who has entered into or proposes to enter in a specialization agreement, and after affording the Competition Policy Advocate a reasonable opportunity to be heard, the Board finds that an agreement or proposed agreement is a specialization agreement, and that the implementation of the agreement or proposed agreement is likely to bring about substantial gains in efficiency, wherever they may arise, that will save resources for the Canadian economy, and no attempts have been made by the parties to the agreement or proposed agreement to coerce any person to become a party to the agreement or proposed agreement, subject to the subsections, the Board may, by order, allow the agreement or proposed agreement for a period specified in the order that is not longer than five years calculated from the date of the order or where, pursuant to the subsections, the allowance of the agreement or proposed agreement is made effective after a condition described in the section is fulfilled, for a period specified in the order that is not longer than the period, not exceeding ten years, during which the series of reductions referred to in the conditions is to take place.

The background of this provision reflects a concern that some Canadian companies were undertaking to discontinue production of certain product lines which would then be manufactured in greater volume by another. The registration of these agreements serves to provide the mechanism for a review process whereby the Competition Board would regulate the functioning and effects of such agreements.

It is in order to carefully review these omnibus provisions to ascertain the extent of their potential application to such arrangements as the construction of petrochemical plants, exchange agreements, unitization agreements, etc.

In the area of specialization agreements, it may be necessary to obtain clarification as to the application or non-application of these provisions to unitization agreements between working interest owners 
and royalty owners to develop and operate an oil or gas field as a single lease on a co-operative basis whereby production from most of the producing wells in the field is discontinued so that production from the entire field can be obtained from a few selected wells and allocated to all of the parties in accordance with a predetermined formula. It has been noted that since such arrangements accomplish cost savings and efficiency of operations and maximize conservation of oil and gas resources, they may from time to time be "expressly required" by a governmental authority.

If it can be concluded that such agreements fall squarely within the regulated conduct exemption, the matter may end there. In the alternative, it would appear that the registration requirements will have to be considered, and any potential application to unitization agreements clarified.

\section{8) Price Differentiation}

Bill C-13 further proposes that97 where, on application by the Competition Policy Advocate, and after affording every person against whom an order is sought a reasonable opportunity to be heard, the Board finds that any supplier of an article is engaging in a practice of supplying an article to different customers who are in competition with each other at prices that differ according to the different quantities purchased by them from the supplier, and the supplier referred to above is a major supplier in a market, or is one of the suppliers in a market where the practice is widespread, and the practice has impeded, or is likely to impede, substantially, the expansion of an efficient firm, or a firm that, but for the practice, would be a strong competitor in a market, the Board may make an order directed to the supplier prohibiting him from engaging in future in the practice.

It is proposed that no order may be made against a supplier under this section where the Board, after hearing that supplier, finds that the practice described above engaged in by him is based on a reasonable assessment of the difference in the actual or anticipated cost of supplying customers in different quantities and under different terms and conditions of delivery.

\section{9) Restrictions on Importation and Exportation by Affiliated Companies}

A new section of the Bill provides that98 where, on application by the Competition Policy Advocate, and after affording every person against whom an order is sought a reasonable opportunity to be heard, the Board finds that a corporation carrying on business in Canada has entered into an agreement or arrangement with an affiliate carrying on business outside Canada to substantially restrict the importation or exportation of a product into or from Canada, or has received from or given to an affiliate that carries on business outside Canada a directive, instructions, intimation of policy or other communication that has brought about or, if implemented, would bring about, a substantial restriction in the importation or exportation of a product into or from Canada, and the Board also finds that the restriction is designed to

97. Bill C-13, supra n. 59, s. 31.77(1).

98. Id. s. 31.61 . 
protect the price level in a Canadian market from the influence of lower-priced products from outside Canada, or to protect the price level in a market outside Canada from the influence of lower-priced products from Canada, the Board may, by order, direct that the corporation carrying on business in Canada withdraw forthwith from the agreement, or arrangement, or refrain from enforcing or implementing the communication, as the case may be. 99

No order shall be made under this section in respect of a corporation where the Board is satisfied that the corporation does not account for twenty-five per cent or more of the production or supply in Canada of the product in relation to which an application is made for an order against the corporation.

\section{E. New Criminal Offences}

\section{1) Import and Export Conspiracies 100}

This section would apply only in respect of conspiracies, combinations, agreements and arrangements whereby one or more persons who carry on business in Canada conspire, combine, agree or arrange with a person or persons who carry on business outside Canada to restrict the importation of a product into Canada, reduce or limit the value of exports of a product from Canada, or adversely affect competition in Canada in a manner otherwise than as described above. Every one who is party to a conspiracy, combination, agreement or arrangement to which this section applies is guilty of an indictable offence and is liable to a fine in the discretion of the court, or to imprisonment for five years, or both unless it is in respect of an agreement or arrangement that is specifically authorized by an Act of Parliament, or that is entered into only by persons, each of whom is an affiliate.

There shall be no conviction where it may be established that the accused does not account for fifty per cent or more of the production or supply in Canada in relation to which the prosecution was brought.

\section{2) Systematic Delivered Pricing}

A new offence to be known as "systematic delivered pricing" 101 is proposed in Bill C-13. It will now be an offence, subject to up to two years imprisonment, if a supplier of an article, in dealing wih one of his customers in Canada, refuses such customer sale and delivery of the article at any locality at which the supplier makes delivery of the article to any other of his customers, on the same terms and conditions of sale and delivery that would be available to the first-mentioned customer if his place of business were located in that locality.

F. Class Actions

Bill C-13 contains provisions designed to facilitate the launching of class actions resulting from violations of the Act and is in accordance with certain of the recommendations contained in a report published in May, 1976102 concerning the matter of class actions.

99. Id.

100. Id. s. 32.1

101. Id. s. 38.1 .

102. See Williams \& Whybrow, A Proposal for Class Actions Under Competition Policy Legislation 236 (1976). 
The section provides for a right of class action under prescribed circumstances in cases where damages are incurred. In addition to providing for damage awards, the Bill proposes to authorize the issuance of injunctions and other remedies to prevent the repetition of damage of a similar nature in future.

G. Appeals

The review and appeal proposed in Bill C-13 is patently inadequate and must be reconsidered in view of the potential impact of Board orders on Canadian business.

Bill C-13 suggests that where the Board makes an order ${ }^{103}$ directing the dissolution of a merger, or disposition of assets or an order not to proceed with a merger, or makes a divestiture order in the case of monopolization, 104 or a divestiture order in the case of joint monopolization, ${ }^{105}$ or an order refusing to allow a specialization agreement, or revokes the allowance of a specialization agreement, 106 the Governor in Council (the Cabinet) only on the recommendation of the Minister of Consumer and Corporate Affairs made within sixty days after receipt of such recommendation, may annul such order, or, in the case of specialization agreements, annul the order and allow the specialization agreement or the modification of the specialization agreement that the Board refused to allow or reinstate the allowance that was revoked.

The Canadian Petroleum Association has recommended 107 that to the extent that Cabinet review is to take place, it should proceed with respect to all Board orders without restriction. The Association recommended that Cabinet review should not be conditional upon the recommendation of any Minister, but should be available as of right to any interested party. There is legislative precedent for this recommendation in the National Transportation Act, ${ }^{108}$ which provides for a review upon petition of any party to vary or rescind any order, decision, rule or regulation of the Commission.

In addition, the Canadian Petroleum Association has recommended that provision be made in Bill $\mathrm{C}-13$ for a full right of appeal on the merits to the Federal Court of Appeal with respect to all Board orders.

This procedure is necessitated by the extremely limited scope available under the Federal Court Act. ${ }^{109}$ A series of decisions clearly establish that the Federal Court cannot set aside a decision simply because it would have reached a different result, 110 but is obliged to act only where a tribunal has failed to observe a principle of natural justice, refused to exercise its jurisdiction, erred in law or based its decision or order on an erroneous finding of fact that it made in a perverse or capricious manner."11

103. Bill C-13, supra n. 59, s. 31.91(1).

104. Id. s. 31.92(3)(c).

105. Id. s. 31.73(3)(c).

106. Id. s. 31.76.

107. Canadian Petroleum Association, supra n. 79 at 1.

108. R.S.C. 1970 , c. N-17, as amended, s. 64.

109. R.S.C. 1970, c. 10 (2nd Supp.).

110. Central Broadcasting Co. Ltd. v. Canadian Labour Relations Board (1975) 57 D.L.R. (3rd) 764.

111. Federal Court Act, supra n. 109, ss. 28(1)(a), (b) and (c). 
VII. REPORT OF THE ROYAL COMMISSION ON CORPORATE CONCENTRATION "THE BRYCE COMMISSION REPORT"

A discussion of recent developments in Canadian competition policy would be incomplete without reference to the Bryce Commission Report, submitted to the Governor General in Council by R.W.V. Dickerson and P.A. Nadeau in March, 1978.112

The Bryce Commission was appointed under Part I of the Inquiries Act113 by two Orders in Council approved respectively on April 22 and May 1, 1975. It was directed to inquire into, report upon, and make recommendations concerning the nature and role of major concentrations of corporate power in Canada, the economic and social implications for the public interest of such concentrations, and whether safeguards exist or may be required to protect the public interest in the presence of such concentrations.114

It is significant to note that despite the fact that the Bryce Commission was engaged in conducting a thorough and intensive review of many of the major issues related to policy matters which should underly the implementation of any effective legislative program, the government of Canada nonetheless introduced Bill C-42 on March 16, 1977 and its successor, Bill C-13, on November 18, 1977. The Bryce Commission was appointed, in part, in response to the bid for control of Argus Corporation Limited made in March/April 1975 by Power Corporation of Canada, Limited. At that time the government concluded that it was not able to adequately assess the full implications of such an acquisition as there had not been, in Canada, any general review and analysis of the consequences of mergers of large, diversified firms or of the implications of concentrations of corporate ownership and power.

The general conclusions 115 contained in the Bryce Commission Report are significant. It is anticipated that they will be carefully reviewed and analyzed in view of the thoroughness of the report and the impact which the report should have in determining the future of Canadian competition legislation.

The report concludes,116 inter alia, that in several countries, the largest firms in industry have been encouraged to merge to increase their international competitiveness. If, in many industries, large size is necessary for efficient operation and competition in international markets, efforts in Canada to reduce corporate concentration by limiting the size of firms will further reduce the competitiveness of Canadian firms in world markets.

While the report recognizes the importance of adequate competition law as an essential instrument of public policy wishing to preserve the advantages of market competition in an oligopolistic economy, it considers that Bill C-13 has gone too far in the areas of "joint monopolization" and "mergers". It concludes that the merger provisions in

112. Report of the Royal Commission on Corporate Concentration (1978) (hereinafter referred to as the "Bryce Commission Report").

113. R.S.C. 1970 , c. I-13.

114. Bryce Commission Report, supra n. 112 , xix.

115. Id. at 405.

116. Id. at 406 . 
Bill C-13 are "misguided, unnecessarily elaborate and expensive", given the small dimensions of the problem with which they are intended to deal.117 The report further notes that these provisions will introduce a degree of risk and uncertainty into Canada's economic environment which cannot be accepted at this time.

The Bryce Commission Report also deals, in brief, with the issue of "regulated industries". It concludes that we now have a collection of laws and machinery by which the state attempts to direct business activity for a variety of poorly coordinated economic and social objectives, and recommends that a detailed study of the problems of the regulated industries be undertaken to alleviate many of the uncertainties (some of which are referred to in this paper) arising out of conflicts within regulatory mechanisms at both the provincial and federal level.

\section{CONCLUSIONS AND RECOMMENDATIONS}

The evolution of Canadian combines legislation reflects a constant balancing by both legislators and legislative draftsmen of a variety of interests, viewpoints and objectives within the context of a constantly changing business community and economic environment.118

The legislative draftsmen have responded by preparing legislation intended to promote healthy competition. The legislation has been drafted in general terms applicable to the whole economy. It is inevitable that what may be a useful statutory provision in one area may have the reverse effect in another, and work against the basic overall objectives of the legislation itself.

The response to the inadequacies of legislative enactments from government, in many cases, has been to provide informal assurances that legislative provisions which might be construed to apply to a specific activity will not be so applied, despite the powerful sanctions which are potentially applicable in the event a violation does occur.

Recent studies show that this particular observation, clearly reflected in Bill C-13, is part of a larger current trend in legislative drafting technique.

An excellent study 119 into this topic recently initiated by the Canadian Manufacturers' Association concluded, inter alia, that there is an overall lack of framework or plan linking various statutes within federal and provincial jurisdictions and between jurisdictions. It was noted that there is a distinct trend towards vesting vast amounts of power in the hands of the bureaucracy by virtue of the fact that the bureaucracy is charged with the duty to administer vague, rather than precise, standards. In turn, this has resulted in the potential for improper delegation of de facto power in the hands of the bureaucracy to change the law in complete isolation from Parliamentary review.

The application of these comments to Bill C-13 should be clearly apparent, and should prompt further industry response.

117. Id. at 408.

118. See Competition Policy in the Context of a Canadian Industrial Strategy I (Proceedings of the 7th McGill-Government-Industry Conference, Nov. 1972).

119. McLaren and Welling, Legislative Research Project Report (1976). 
Insofar as existing legislation is concerned, it is the absolute responsibility of Canadian corporations to develop within their respective organizations and effective program of compliance with the Combines Investigation Act, giving due consideration to the development of a specific management program and policy geared to education of key personnel, establishment of appropriate internal procedures to implement that policy, and implementation of an appropriate audit procedure. ${ }^{20}$

In relation to proposed legislation, there is an additional responsibility to communicate industry-related concerns to those responsible for the preparation of legislation, indicating the specific effect which legislative changes may have and the industry viewpoint on methods employed. The succesful implementation of both of these approaches by industry will be of considerable importance in assuring that a proper evolution of Canadian competition policy will take place in future.

120. Anderson, Anti-Trust Compliance in Action (1975) 20 Antitrust Bulletin 781. 


\section{APPENDIX A}

Extract from the Report of the Committee to Study Combines Legislation Ottawa, The Queen's Printer, 1952 pp. 9-15. 


\title{
APPENDIX A
}

\author{
Extract from the Report of the \\ Committee to Study Combines Legislation \\ Ottawa, The Queen's Printer, 1952 pp. 9-15.
}

The Period:

$1889-1910$

Canadian combines legislation had its origin in the report of a Select Committee of the House of Commons appointed in 1888 to inquire into the existence of combinations and trusts in Canada, and their effect upon the Canadian economy. The Committee found that combinations inimical to the public interest existed in respect of a number of widely used commodities and services and recommended that legislative action be taken to curb such combinations. In 1889 an Act was passed, the parent of section 498 of the Criminal Code, making it a misdemeanour to conspire, combine, agree or arrange unlawfully,

(a) To unduly limit the facilities for transporting, producing, manufacturing, supplying, storing or dealing in any article or commodity which may be a subject of trade or commerce; or

(b) To restrain or injure trade or commerce in relation to any such article or commodity: or

(c) To unduly prevent, limit, or lessen the manufacture or production of any such article or commodity, or to unreasonably enhance the price thereof; or

(d) To unduly prevent or lessen competition in the production, manufacture, purchase, barter, sale, transportation or supply of any such article or commodity, or in the price of insurance upon person or property.

In the general codification of the criminal law in 1892, the Act of 1889 became a section of the Criminal Code and the offence was made an indictable one. The awkward usage involved by employing the term "unlawfully" as well as "unduly" and "unreasonably" to describe the offence led to early difficulties of interpretation, and after various legislative amendments, the word "unlawfully" was eliminated from the section in 1900, and the wording settled in the form it has retained to the present time.

In its improved wording the section provided the basis for six prosecutions in the next ten years, four of these resulting in convictions. In addition, the courts found agreements brought before them in a number of civil suits to be illegal as contrary to the section and refused the parties to the agreements any rights under them. In most of these instances, however, no criminal prosecution followed. Experience showed increasingly that, in combines cases, the problem of securing evidence was a peculiarly difficult one. In one instance, in this period, it was found necessary to resort to the appointment of a Parliamentary Committee to assemble the facts. It was a task normally beyond the resources of private individuals or the ordinary machinery of criminal legislation. 
The Period:

$1910-1919$

The Combines Investigation Act of 1910 sought to supply, for this weakness, special machinery of investigation. Any six persons could apply to a judge for an order directing that an investigation into an alleged combine be held.

A combine was defined by the Act as (a) "any contract, agreement, arrangement or combination which has, or is designed to have, the effect of increasing or fixing the price or rental of any article of trade or commerce or the cost of the storage or transportation thereof, or of restricting the competition in or of controlling the production, manufacture, transportation, storage, sale or supply thereof to the detriment of consumers or producers of such article of trade or commerce", including (b) "the acquisition, leasing, or otherwise taking over, or obtaining by any person to the end aforesaid of any control over or interest in the business, or any portion of the business of any other person"; and (c) "includes what is known as a trust, monopoly or merger".

If, after hearing, the judge found the situation to warrant an inquiry he could issue an order to that effect. The Minister of Labour was then to appoint a board of three commissioners, one selected by the applicants, one by the parties against whom the application was made, and the third, the chairman, who was ta be a judge, nominated by the other two members. A board had power to compel the attendance of witnesses, examine them under oath, require the production of documents and general incidental powers to carry out a full inquiry.

A board had wide powers of report; it could make "such findings and recommendations as, in the opinion of the board, are in accordance with the merits and requirements of the case". Reports were to be transmitted to the Minister at the conclusion of any inquiry and to be published in the Canada Gazette.

Any person who was found by the board, after inquiry, to have done any of the enumerated acts being the same as those mentioned in section 498 of the Criminal Code, and who did not cease his activities within ten days after the publication of a report to this effect, made himself, under the Act, liable to per diem penalty up to one thousand dollars for each day he continued to offend.

The Act of 1910 also carried forward a provision (which had first found place in Canadian legislation in 1897) for the use of tariff action to combat monopolistic practices. The Customs Tariff Act of $1897 \mathrm{had}$ given authority for the government to have an investigation held by a judge into the existence of a trust or combination that unduly enhanced prices or promoted the advantage of manufacturers or dealers at the expense of consumers. If such a trust or combination were found to exist, the duty on the commodity or commodities affected could be lowered or removed by executive action. By the Act of 1910 this action could be taken when a board or a court had found such a combination existed. Furthermore an additional remedy was provided where a board reported that the owner or holder of a patent had made use of the exclusive rights under it to do any of the enumerated acts being the same as those mentioned in section 498 of the Criminal Code. In 
such cases the Minister of Justice could institute appropriate proceedings in the Exchequer Court to have the patent revoked.

The expectation was that, through its provision for public investigation and report, the Act would, in considerable measure, deter harmful activities without resort to prosecution; and that this failing, and prosecution becoming necessary, the new procedures for the discovery and marshalling of facts would facilitate the process of prosecution. In fact, the machinery of the Act was only used once before the country was swallowed up in the concerns of the First Great War. The legislation revealed two prime weaknesses. The first was that private citizens, six in number for each application, were reluctant to shoulder the considerable responsibility, by way of expense and publicity, of initiating investigations. Secondly, there was no individual or body to provide continuity in the administration of the legislation. A board was constituted on an ad hoc basis. Upon completion of the investigation and the submission of a report the board ceased to function. There was consequently no machinery to determine whether the recommendations of the report were being carried out or not.

The Period:

1919 - 1923

The rapid rise in the cost of living which was an immediate economic aftermath of the First Great War led to the appointment of a special committee of the House of Commons in 1919. The committee recommended the setting up of a permanent board to administer legislation dealing with trade combinations and monopolies as well as with profiteering and hoarding.

The consequent legislation set up a permanent board, the Board of Commerce, consisting of three commissioners. The Board was charged with the administration of the Combines and Fair Prices Act. Under this Act the function of the board was two-fold. The first was the investigation and restraining of combinations, monopolies, trusts and mergers constituting a combine and the second, control over the withholding of and the enhancement of prices of commodities.

Under the First Part of the Act, the Board could begin an inquiry either upon its own initiative or upon a formal application made to it by one person. It had extensive powers of investigation and, at the conclusion of its proceedings, could make orders requiring persons to cease and desist from any practices found to be contrary to the Act. The Act defined "combine" as one which, in the opinion of the Board, operated or was likely to operate to the detriment or against the interest of the public and was deemed to include:

(a) mergers, trusts and monopolies, so called, and

(b) the relation resulting from the purchase, lease or other acquisition by any person of any control over or interest in the whole or part of the business of any other person, and

(c) any actual or tacit contract, agreement, arrangement or combination which has or is designed to have the effect of (1) limiting facilities for transporting, producing, manufacturing, supplying, storing or dealing; or (2) preventing, or limiting or lessening manufacture or production; or (3) fixing a common price, or a resale price, or a common rental, or a common cost of storage or transportation, or enhancing the price, rental or cost of an article, rental, storage or transportation; or (4) preventing or lessening competition in, or substantially controlling, within any particular district, or generally, production, manufacture, purchase, barter, sale, transportation, insurance or supply; or (5) otherwise restraining or injuring commerce. 
A person who failed to obey an order of the Board was guilty of an indictable offence and the Board might remit a case to the AttorneyGeneral of a province for prosecution.

The Act also carried forward the tariff and patent provisions that had been included in the Combines Investigation Act of 1910.

The Act in its Second Part prohibited hoarding and profiteering. The Board was empowered and directed to inquire into and to restrain and prohibit any breach or non-observance of the Act, the making of unfair profits, and all such practices with respect to the holding or disposition of the necessaries of life, as, in the opinion of the Board, were calculated to enhance their cost or price.

It is to be observed that the legislation overcame two of the principal defects of the Act of 1910, namely the absence of a continuing enforcement authority, and the initiation of investigations only on the application of interested private individuals.

The Board entered upon an active life which, however, was cut short when its powers were called in question in a constitutional reference to the courts in 1920. After an equal division of judicial opinion in the Supreme Court of Canada, the Judicial Committee of the Privy Council in 1921, on appeal, held that because of the administrative features of direct control contained in it, the legislation was beyond the competence of the Dominion to enact, and it thereupon ceased to operate.

\section{The Period:}

\section{$1923-1935$}

The Combines Investigation Act of 1923 followed. The comprehensive definition of "combine" of the legislation of 1919 was largely retained but no administrative power to order the cessation of activities was provided for. A permanent Registrar was to administer the Act; to him, either upon formal application of six persons, or upon ministerial direction, or whenever he himself had reason to believe that a combine existed or was being formed, was committed the power to hold a preliminary inquiry. If after the preliminary inquiry the Registrar concluded or the Minister decided that a formal investigation was necessary, such investigation was conducted by the Registrar or by a commissioner appointed ad hoc.

At the conclusion of the formal investigation a report was transmitted to the Minister, and in the case of a commissioner's report had to be made public within fifteen days of its receipt by the Minister except in those cases where the commissioner had recommended that its publication be withheld, in which event the Minister might exercise his discretion as to publication of the report either in whole or in part.

The Act made it a criminal offence to be a party or privy to or knowingly to assist in the formation or operation of a combine. A person found guilty of an offence was liable to a penalty not exceeding $\$ 10,000$ or two years imprisonment, in the case of individuals, and a penalty not exceeding $\$ 25,000$ in the case of corporations.

The earlier provisions relating to executive action in respect of tariffs and judicial revocation of patent rights were continued in the new legislation. 
The legislation of 1923 after a number of investigations had been held under it, in turn came under a challenge on constitutional grounds. On a reference as to the validity both of the Combines Investigation Act and section 498 of the Criminal Code, the Judicial Committee of the Privy Council in 1931 held, affirming a judgment to the same effect by the Supreme Court of Canada, the enactments to be within the powers of the Federal Parliament as being legislation in relation to criminal law.

\section{The Period:}

$1935-1951$

In 1935, consequent upon a review of combines legislation as part of a larger inquiry into price spreads and trade practices generally, the Dominion Trade and Industry Commission Act of that year created a three-man commission (the members of the existing Tariff Board constituted, under the Act, the commission) to which the administration of the Combines Investigation Act, including the power to initiate and conduct investigations, was transferred.

The existing provisions for investigation and report accordingly continued; but the new Act also empowered the Commission if it found, as a result of an investigation under the Combines Investigation Act, that wasteful or demoralizing competition existed in an industry, and that agreements among persons in the industry to modify competition would not unduly restrain trade or operate against the public interest, to recommend approval of such agreements to the Governor in Council. It could also recommend approval where, in its opinion, existing agreements prevented wasteful or demoralizing competition and did not operate against the public interest. The Governor in Council, if of opinion that the conclusions of the Commission were well founded, could approve the agreements and make regulations requiring the Commission to keep a check on the effect of the agreements.

The Commission had the power to require any persons engaged in the industry subject to an approved agreement to furnish full information relating to the operations of the industry, and, on its own motion and in its absolute discretion, could recommend to the Governor in Council that approval of an agreement should be withdrawn.

Approval of an agreement was a bar to prosecution under the Combines Investigation Act or section 498 or $498 \mathrm{~A}$ of the Criminal Code except in cases where the Commission gave its consent to such a prosecution.

The Commission could also investigate complaints of unfair trade practices and forward the complaint and any evidence in support thereof to the Attorney-General of Canada with a recommendation for prosecution if it appeared that any federal law prohibiting unfair trade practices had been violated. For the purposes of prosecution, a Director of Public Prosecutions, appointed under the Act, had the conduct of federal prosecutions and could assist provincial authorities when they instituted proceedings in trade practice cases, besides being available to assist the Commission with investigations into complaints. 
The Commission could in addition hold trade practice conferences attended by persons engaged in a particular industry for the purpose of considering the trade practices in that industry and determining which were unfair or undesirable in the interest of the industry and of the public. Such conferences could be called by the Commission on the direction of the Governor in Council, at the request of representative persons engaged in the industry, or on its own motion. The Commission could make public the general opinion of the conference or of the Commission as to any trade practice considered to be unfair or undesirable.

The Commission was authorized to co-operate with boards of trade and chambers of commerce in connection with any commercial arbitration. On the direction of the Governor in Council it could conduct general economic studies.

A constitutional reference to the Supreme Court instituted shortly after the Act was passed established that the authority conferred on the Commission by section 14 of the Act to approve agreements limiting competition was beyond federal legislative power. The investigatory provisions were untouched by the decision. Though in form the Board continued to have legal existence until 1949 and from 1937 to 1946 shared jurisdiction over combines with the Commissioner under the Combines Investigation Act, in point of fact the Board did not exercise any functions in respect of the Combines Investigation Act. From 1946 to 1951, both legally and in fact, the Commissioner was alone in his position as officer in charge of the Act.

The principal change made by the legislation of 1937 was to restore the administration of the Combines Investigation Act to a single official. The office of the Registrar, which had existed since 1923, was abolished and that of a Commissioner substituted. The machinery for the appointment of special, or ad hoc, commissioners was retained. The provision requiring the publication or reports included the reports of the permanent Commissioner and he normally conducted most of the investigations under the Act. This was a reversal of the former practice. After 1937 the role of the special commissioner was merely to supplement the staff of the Commission when an immediate investigation was desirable and the Commissioner was already engaged in other duties.

\section{The Period:}

$1951-1966$

The principal Canadian legislation (in 1951)* was contained in section 498 of the Criminal Code and in the Combines Investigation Act. The former made it an offence to combine or conspire to do certain acts in restraint of trade; the latter to a large extent overlapped with the provisions of section 498 by making it an offence to participate in the formation or operation of a combine and also set up machinery by which inquiry as to the existence of a combine was to be carried out.

* Minor editorial revision added. 
The Act was under the general administration of a Commissioner, who had one or more Deputy Commissioners to assist him. By Orderin-Council special commissioners were appointed to conduct particular investigations.

Investigations began in one of three ways. One was the lodging with the Commissioner of an application by six private citizens, a procedure which first appeared in the Act in 1910 but was rarely put to use either under that Act or the Act of 1951. A second method is a direction from the Minister to launch an inquiry; but this method was not much used, particularly since the Commissioner was given an independent initiative in 1946. Nearly all investigations, in practice, originated with the Commissioner, the requirement in that case being that he have reason to believe that a combine exists or is being formed.

A series of further amendments followed in the years 1951 to $1966^{*}$, the most notable of which related to the instigation of prohibitions against resale price maintenance in 1951, and the restructuring of the branch requiring investigations to be undertaken by the Director of Investigation and Research, who would then report to the Restrictive Trade Practices Commission. In addition, in 1960, sections 411 and 412 relating to conspiracies in restraint of trade and price discrimination, previously contained in the Canadian Criminal Code, were consolidated with the Combines Investigation Act, and definitions were introduced with respect to the expressions "merger" and "monopoly"; terms which have been carried through and further developed in both the present and proposed legislation and by judicial review.

*An Act to Amend the Combines Investigation Act 1951 (2nd Sess.) c.30; An Act to amend the Combines Investigation Act and the Criminal Code, 1952, c.39; Combines Investigation Act, R.S. 1952, C.314; Criminal Code, 1953.54, c.51, s.750; An Act to Amend the Combines Investigation Act and the Criminal Code, 1960, c.45; An Act to Amend an Act to Amend the Combines Investigation Act and the Criminal Code, 1960-61, c.42; An Act to Amend An Act to Amend the Combines Investigation and the Criminal Code, 1962-63, c.4; Government Organization Act, 1966, c.25; Department of Consumer and Corporate Affairs Act, 1968-69, c.38; An Act to Amend the Canada Coporations Act, 1969-70, c.70; Federal Court Act, 1970-71-72, c.1. 